\title{
IMPLEMENTASI EMIS TANGGAP COVID-19 DALAM PEMANTAUAN KESIAPAN MADRASAH PADA MASA PANDEMI COVID-19 DI KEMENTERIAN AGAMA KABUPATEN MOJOKERTO
}

\author{
Fitria Hindahsari, Rizki Ayuningtyas, Wahyu Aji Lusdianto. \\ UIN Sunan Ampel, Surabaya - Indonesia | hindahsarif@gmail.com
}

\begin{abstract}
Abstrak: Tujuan penelitian ini adalah mendeskripsikan pengelolaaan EMIS Tanggap Covid-19, pemantauan kesiapan madrasah malalui EMIS Tanggap Covid-19, Faktor pendukung, dan faktor penghambat EMIS Tanggap Covid-19 dalam pemantauan kesiapan madrasah pada masa pandemi Covid-19 Penelitian ini menggunakan metode kualitatif deskriptif dengan informan penelitian operator EMIS pada seksi Pendidikan Madrasah Kementerian Agama Kabupaten Mojokerto. Metode pengumpulan data yang digunakan dalam penelitian ini adalah observasi, wawancara, dan dokumentasi. Hasil penelitian menunjukan bahwa 378 madrasah di Kabupaten Mojokerto telah mengisi daftar kesiapan satuan pendidikan melalui EMIS Tanggap Covid-19 dari 378 madrasah yang merespon belum mendapat persetujuan untuk memulai pembelajaran tatap muka dikarenakan Kabupaten Mojokerto termasuk zona merah sehingga belum mendapatkan surat rekomendasi dari Satuan Gugus Tugas Covid-19 Kabupaten mojokerto. Faktor pendukung adanya aplikasi EMIS Tanggap Covid-19 dalam pemantauan kesiapan madrasah yaitu kompetensi Oprator EMIS, sarana dan prasarana, data yang valid, komitmen madrasah, sedangkan faktor penghambatnya yaitu sulitnya jangkauan jaringan untuk mengakses aplikasi Emis Tanggap Covid-19 di waktu-waktu tertentu dan terdapat beberapa madrasah yang belum merespon EMIS Tanggap Covid-19 sehingga menghambat proses pemantauan kesiapan madrasah pada masa pandemi Covid-19..
\end{abstract}

Keywords: emis, pandemic, madrasah

\section{Pemdahuluan}

Pada bulan Desember 2019 di kota Wuhan, China terjadi penyebaran virus baru yaitu coronavirus jenis SARS-CoV-2 yang 
menyebabkan terjadinya penyakit Coronavirus Disease 2019 (Covid-19). Virus corona ini menimbulkan gejala klinis demam, batuk, kesulitan bernafas hingga menyebabkan kematian. Virus corona telah banyak menyebar ke lebih dari 210 negara. Data jumlah kasus aktif pada 5 Oktober 2020 tercatat sebanyak 7,7 juta kasus dengan 7,6 kasus dalam kondisi ringan, dan 66.421 dalam kondisi serius atau kritis. Dan jumlah kasus terbanyak masih dicatatkan oleh Amerika Serikat (AS) dengan lebih dari 7,6 juta kasus.

Indonesia sendiri berada di posisi ke-23 negara dengan jumlah kasus terbanyak dengan total 299.506. Sementara di Asia, Indonesia berada di urutan ke-9 setelah India dan Iran. Namun, jumlah kematian di Indonesia cukup tinggi di Asia. Indonesia berada di urutan ke-3 negara Asia dengan jumlah kematian terbanyak, yaitu 11.055 jiwa data berdasarkan pada tanggal 4 oktober 2020 .

Tingginya angka penyebaran virus corona ini menyebabkan terjadinya pembatasan sosial sehingga banyak segala aktivitas diluar rumah ditiadakan. Khususnya dalam dunia pendidikan banyak lembaga pendidikan meniadakan pembelajaran tatap muka dan digantikan dengan pembelajaran daring. Pemerintah Indonesia harus mengambil keputusan sejak bulan Maret menghentikan aktifitas pembelajaran di sekolah untuk mencegah penyebaran virus corona di lembaga pendidikan. Dengan dilakukannya penutupan sekolah, dan pembelajaran dilakukan secara online (Daring) menyebabkan proses pembelajaran kurang maksimal karena terdapat beberapa guru, siswa, dan orang tua yang asing dengan penggunaan teknologi komunikasi. dan belum mengetahui metode pebelajaran online sehingga proses pembelajaran hanya berlangsung dengan pemberian tugas pada siswa, sehingga siswa kesulitan memahami pelajaran.

Pada awal tahun pembelajaran 2020/2021 ditetapkan pembelajaran tatap muka dapat dilakukan kembali pada lembaga pendidikan yang berada di zona hijau. Perbedaan zona penyebaran Covid-19 di Inodonesia berbeda-beda sehingga tidak semua lembaga pendidikan pada tahun ajaran baru diizinkan untuk memulai kembali pembelajaran tatap muka. Adanya perbedaan 
zona penyebaran Covid-19 dan untuk menilai kesiapan madrasah kembali melaksanakan pembelajaran tatap muka Direktorat Jendral Pendidikan Islam membuat EMIS Tanggap Covid-19 sebagai sistem informasi manajemen yang digunakan untuk mendata kesiapan madrasah untuk memulai kembali pembelajaran tatap muka.

EMIS Tanggap Covid-19 (ETC-19) adalah aplikasi yang berbasis web yang dijadikan salah satu dasar dalam pengambilan sebuah kebijakan bagi Direktorat Jenderal Pendidikan Islam, Perguruan Tinggi Keagaamaan Islam, Kanwil Kemeanterian Agama Provinsi dan Kementerian Kabupaten/Kota dalam mempersiapkan penyelenggaraan pembelajaran pada tahun ajaran baru dan ajaran akademik baru tahun 2020-2021 di masa pandemi Covid-19.

Implementasi secara sederhana dapat diartikan sebagai pelaksanaan atau penerapan. Sebagaimana yang ada di dalam Kamus Besar Bahasa Indonesia (KBBI), Implementasi berarti penerapan. Browne dan Wildavsky mengemukakan bahwa "Implementasi adalah perluasan aktivitas yang saling menyesuaikan". Adapun Schubert mengemukakan bahwa "Implementasi adalah sistem rekayasa".Pengertian-pengertian diatas memperlihatkan bahwa kata Implementasi bermuara pada aktivitas, adanya aksi, tindakan, atau mekanisme suatu sistem. Ungkapan mekanisme mengandung arti bahwa Implementasi bukan sekedar aktivitas, tetapi suatu kegiatan yang terencana dan dilakukan secara sungguh-sungguh berdasarkan acuan norma tertentu untuk mencapai tujuan kegiatan. Dari pengertian diatas, Implementasi dapat diartikan sebagai penerapan atau operasionalisasi suatu aktivitas guna mencapai suatu tujuan atau sasaran.

Pemantauan digunakan untuk mengumpulkan data dan informasi dari sebuah kebijakan/program/kegiatan. Pemanatauan dan evaluasi mengukur dan menilai hasil/kemajuan dari pelaksanaan kebijakan/program/kegiatan, yang dilaksanakan dengan cara dan waktu yang berbeda. Pemantauan umumnya dilakukan pada saat pelaksanaan kebijakan/program/kegiatan, sedangkan evaluasi dapat dilakukan pada berbagai tahapan 
pelaksanaan kebijakan/program/kegiatan (sebelum, pada saat, dan setelah pelaksanaan).

Pemantauan adalah sebuah proses yang berlanjut dengan menggunakan metode pengumpulan data yang sistematis terkait indikator tertentu bagi kepentingan manajemen dan stakeholder yang berhubungan dengan intervensi yang sedang dilakukan, untuk melihat kemajuan dan pencapaian sasaran serta penggunaan dana yang dialokasikan. Pemantauan adalah proses untuk menilai kemajuan pembangunan secara berkelanjutan dan periodik pada berbagai tingkatan hirarki institusi, yang dimaksudkan agar input dan sumber daya yang diimplementasikan dikerjakan secara baik.

Implementasi EMIS Tanggap Covid-19 dirasa sangat cukup membantu proses pemantauan maupun dapat mempercepat kinerja Kementerian Agama Kabupaten/Kota. Peran data dalam pengambilan keputusan merupakan hal yang sangat penting. Karena dengan adanya data yang valid, akurat, dan mudah untuk diakses akan menentukan kebijakan yang diambil oleh seorang pengambil keputusan. EMIS juga menyediakan data lapangan yang berasal dari madrasah-madrasah sebagai data awal dan data lapangan yang bisa digunakan sebagai dasar pengambilan keputusan.

Berdasarkan Surat Keputusan Bersama Menteri Pendidikan Dan Kebudayaan, Menteri Agama, Menteri Kesehatan, Dan Menteri Dalam Negeri Republik Indonesia Nomor 01/Kb/2020, Nomor 516 Tahun 2020, Nomor Hk.03.01/Menkes/363/2020, dan Nomor 440-882 Tahun 2020 Tentang Panduan Penyelenggaraan Pembelajaran Pada Tahun Ajaran 2020/2021 Dan Tahun Akademik 2020/2021 Di Masa Pandemi Corona Virus Disease 2019 (Covid-19). Pembelajaran tatap muka di satuan pendidikan pada tahun ajaran 2020/2021 dan tahun akademik 2020/2021 sebagaimana dimaksud dalam Diktum kesatu tidak dilakukan secara serentak di seluruh wilayah Indonesia dengan ketentuan sebagai berikut:

- Satuan pendidikan yang berada di daerah zona hijau dapat melakukan pembelajaran tatap muka di satuan pendidikan setelah mendapatkan izin dari pemerintah daerah melalui dinas pendidikan provinsi atau kabupaten/kota, kantor wilayah 
Kementerian Agama provinsi, dan kantor Kementerian Agama kabupaten/kota sesuai kewenangannya berdasarkan persetujuan gugus tugas percepatan penanganan Covid-19 setempat;

- Satuan pendidikan yang berada di daerah zona kuning, oranye, dan merah, dilarang melakukan proses pembelajaran tatap muka di satuan pendidikan dan tetap melanjutkan kegiatan Belajar Dari Rumah (BDR).

- Kepala satuan pendidikan pada Madrasah baik MI, MTs, MA pada semua zona wajib mengisi daftar periksa pada laman Education Management Information System (EMIS) Kementerian Agama untuk menentukan kesiapan satuan pendidikan sebagaimana tercantum dalam ketentuan.

Pemerintah Daerah, Kantor Wilayah Kementerian Agama Provinsi dan/atau, Kantor Kementerian Agama kabupaten/Kota sesuai dengan kewenangannya pada semua zona:

- Wajib memastikan seluruh kepala satuan pendidikan mengisi daftar periksa pada laman EMIS untuk menentukan kesiapan satuan pendidikan; dan

- Tidak memperbolehkan pembelajaran tatap muka di satuan pendidikan bagi:

- Satuan pendidikan yang belum memenuhi semua daftar periksa; atau

- Satuan pendidikan yang sudah memenuhi daftar periksa namun kepala satuan pendidikan menyatakan belum siap.

Pemerintah Daerah, Kantor Wilayah Kementerian Agama Provinsi dan/atau, Kantor Kementerian Agama Kabupaten/Kota sesuai dengan kewenangannya pada zona hijau dapat melakukan pembelajaran tatap muka di satuan pendidikan secara bertahap selama masa transisi bagi satuan pendidikan yang sudah memenuhi semua daftar periksa dan merasa siap. Pembelajaran tatap muka di satuan pendidikan pada zona hijau dilakukan dengan penentuan prioritas berdasarkan jenjang pendidikan yang lebih tinggi terlebih dahulu dan mempertimbangkan kemampuan peserta didik untuk menerapkan protokol kesehatan dan menjaga jarak Physical Distancing dengan ketentuan : Madrasah Aliyah (MA), Madrasah 
Aliyah Kejuruan (MAK), Madrasah Tsarrawiyah (MTs), melaksanakan pembelajaran tatap muka di satuan pendidikan terlebih dahulu. Madrasah Ibtidaiyah (MI) paling cepat 2 (dua) bulan setelah MA, MAK, dan MTs melaksanakan pembelajaran tatap muka di satuan pendidikan. Raudatul Athfal (RA) paling cepat 2 (dua) bulan setelah MI melaksanakan pembelajaran tatap muka di satuan pendidikan.

Bagi satuan pendidikan yang sudah memulai pembelajaran tatap muka di satuan pendidikan yang berada di daerah zona hijau, orang tua/wali peserta didik tetap dapat memilih untuk melanjutkan bdr bagi anaknya. Pemerintah daerah, kantor wilayah kementerial agama provinsi, dan/atau kantor kementerian agama kabupaten/kota sesuai dengan kewenangannya pada zona hijau wajib menutup kembali pembelajaran tatap muka di satuan pendidikan dan melakukan BDR apabila terindikasi dalam kondisi tidak aman atau tingkat risiko daerahnya berubah.

Dalam mempersiapkan pembelajaran tatap muka di satuan pendidikan, Kepala Kantor Wilayah Kementerian Agama Provinsi, dan Kepala Kantor Kementerian Agama Kabupaten/Kota sesuai kewenangannya bertanggung jawab untuk:

- Memastikan kesiapan satuan pendidikan untuk pembelajaran tatap muka dengan aman termasuk melakukan evaluasi terhadap pengisial daftar periksa di EMIS;

- Menentukan pembukaan satuan pendidikan berdasarkan hasil evaluasi daftar periksa kesiapan pembelajaran tatap muka di satuan pendidikan

- Menugaskan pendidik dari satu satuan pendidikan ke satuan pendidikan yang lain jika diperlukan.

- Berkoordinasi dengan gugus tugas percepatan penanganan COVID-19 dan/ atau dinas kesehatan setempat;

- Memberikan peningkatan kapasitas kepada pengawas madrasah, kepala satuan pendidikan, dan pendidik mengenai penerapan protokoi kesehatan, dukungan psikososial, pemanfaatan teknologi informasi dalam pembelajaran, mekanisme pembelajaran jarak jauh, dan mekanisme pelaporan, dengan tetap menerapkan protokol kesehatan. 
Pada saat satuan pendidikan sudah disetujui untuk memulai kembali pembelajaran tatap muka, Kepala Kantor wilayah Kementerian Agama Provinsi, dan Kepala Kantor Kementerian Agama Kabupaten/Kota sesuai kewenangannya bertanggung jawab untuk:

- Melaporkan Perkembangan Pelaksanaan Pembelajaran Di Satuan Pendidikan Kepada Kepala Daerah Dan Melalui Lembaga Penjaminan Mutu Pendidikan (LPMP) Dan Kementerian Agama Sesuai Kewenangan;

- Bersama Dengan Gugus Tugas Percepatan Penanganan COVID19 Setempat Melakukan Evaluasi Pembukaan Satuan Pendidikan; Dan

- Wajib Menutup Kembali Satuan Pendidikan Yang Sudah Dibuka Apabila Terindikasi Dalam Kondisi Tidak Aman.

Kepala Satuan Pendidikan RA, MI, MTs, dan MA Dalam mempersiapkan pembukaan, kepala satuan pendidikan bertanggung jawab untuk:

- Mengisi daftar periksa kesiapan pembelajaran tatap muka satuan pendidikan melalui laman EMIS bagi RA, MI, MTs, MA. Daftar periksa kesiapan satuan pendidikan meliputi:

- Ketersediaan sarana sanitasi dan kebersihan, paling sedikit memiliki toilet bersih, Sarana ctps dengan air mengalir menggunakan sabun atau cairan pembersih tangan (hand sanitizer); dan Disinfektan.

- Mampu mengakses fasilitas pelayanan kesehatan, seperti Puskesmas, klinik, rumah sakit, dan lainnya;

- Kesiapan menerapkan area wajib masker kain atau masker tembus pandang bagi yang memiliki peserta didik disabilitas rungu;

- memiliki thermogun (pengukur suhu tubuh tembak);

- pemetaan warga satuan pendidikan yang tidak boleh melakukan kegiatan di satuan Pendidikan, yaitu memiliki kondisi medis comorbid yang tidak terkontrol; tidak memiliki akses transportasi yang memungkinkan penerapan jaga jarak; memiliki riwayat perjalanan dari zona kuning, oranye, merah dan belum menyelesaikan isolasi 
mandiri selama 14 (empat belas) hari; dan memiliki riwayat kontak dengan orang terkonfirmasi positif covid-19 dan belum menyelesaikan isolasi mandiri selama 14 (empat belas) hari,

- membuat kesepakatan bersama komite sekolah dengan tetap menerapkan protokol kesehatan, terkait kesiapan melakukan pembelajaran tatap muka di satuan pendidikan.

- Membentuk satuan tugas dan dapat melibatkan orang tua/wali peserta didik dan masyarakat sekitar dengan komposisi sebagai berikut:

- Tim pembelajaran, psikososial, dan tata ruang;

○ Tim kesehatan, kebersihan, dan keamanan; dan

- Tim pelatihan dan humas.

- Membuat rencana kegiatan dan anggaran satuan pendidikan (RKAS) terkait pendanaan kegiatan sosialisasi, peningkatan kapasitas, dan pengadaan sarana prasarana sanitasi, kebersihan, dan kesehatan satuan pendidikan.

- Menginformasikan kepada Kantor Wilayah Kementerian Agama Provinsi, dan Kantor Kementerian Agama Kabupaten/Kota sesuai dengan kewenangannya jika ada warga satuan pendidikan di wilayah kewenanganya terkonfirmasi positif Covid- 19.

\section{Metodologi}

Metode penelitian yang digunakan adalah kualitatif deskriptif, hal ini dikarenakan melalui metode tersebut dapat tergambar secara detail permasalahan penelitian, yakni terkait pemantauan kesiapan madrasah melalui aplikasi EMIS Tanggap Covid-19. Sementara informan dalam penelitian yaitu operator EMIS dan kepala madrasah di lingkup Kementerian Agama Kabupaten Mojokerto. Waktu penelitian 23 September - 09 Oktober 2020. Lokasi penelitian yaitu di kantor Kementerian Agama Kabupaten Mojokerto yang beralamat di Jl. R.A. Basuni No.28 A, Mojokerto, Jawa Timur.

Teknik pengumpulan data menggunakan beberapa cara. Pertama, melakukan wawancara terstruktur dengan pedoman wawancara dan juga melakukan wawancara tidak tersetruktur. 
Kedua, peneliti melakukan pengamatan atau observasi terhadap pemantauan kesiapan madrasah melalui aplikasi EMIS Covid-19. Ketiga, peneliti mengumpulkan data melalui dokumentasi.

Teknik analisis data pada penelitian ini dilakukan dalam 3 tahap yaitui reduksi data. penyajian data, penarikan kesimpulan dan verifikasi. Reduksi data adalah proses memilih hal-hal yang pokok, dan memfokuskan pada hal-hal yang penting. Dengan demikan data yang telah direduksi akan memberikan gambaran yang lebih jelas, dan mempermudah peneliti untuk melakukan pengumpulan data selanjutnya.

Setelah data direduksi, maka langkah selanjutnya yaitu menyajikan data. Dalam penelitian ini data disajikan dalam bentuk teks yang bersifat naratif.. Dan langkah terakhir dalam menganalisis data yaitu penarikan kesimpulan dan verifikasi. Kesimpulan awal yang dikemukakan masih bersifat sementara, dan akan berubah apabila tidak ditemukan bukti-bukti yang kuat yang mendukung pada tahap pengumpulan data berikutnya. Tetapi apabila kesimpulan yang dikemukakan pada tahap awal, didukung oleh bukti-bukti yang valid dan konsisten saat peneliti kembali ke lapangan mengumpulkan data, maka kesimpulan yang dikemukakan merupakan kesimpulan yang kredibel.

\section{Hasil dan Pembahasan}

EMIS Tanggap Covid-19 (ETC-19) merupakan aplikasi berbasis web yang digunakan untuk mengakses daftar kesiapan proses belajar mengajar satuan pendidikan dimasa pandemi Covid-19. Pengelolaan EMIS terdiri dari tiga tahap yaitu perencanaan, pelaksanaan hingga evaluasi. Perencanaan adalah langkah yang perlu dilakukan dalam prinsip manajemen untuk mencapai tujuan. Terutama pada Sistem Informasi Manajemen, fungsi perencanaan memiliki peran penting agar program kerja yang akan dilakukan dapat berjalan dengan baik. Perencanaan penggunaan ETC-19 dilakukan dua tahap yaitu:

- Perencanaan perangkat pengumpulan data

Adanya pandemi Covid-19 menyebabkan lembaga pendidikan meniadakan pembelajaran tatap muka sejak bulan Maret. Untuk 
memulai kembali pembelajaran tatap muka salah satu syaratnya lembaga pendidikan menerapkan protokol kesehatan dan lembaga pendidikan berada pada wilayah zona hijau. Adanya situasi tersebut Direktorat Jenderal Pendidikan Islam Kemeterian Agama Republik Indonesia menerbitkan surat edaran mengenai pengisian daftar kesiapan satuan pendidikan memasuki tahun ajaran baru di masa pandemi Covid-19 yang salah satunya ditujukan pada Kantor Wilayah Kementerian Agama Provinsi.

Dari surat edaran tersebut dapat diketahui bahwa Direktorat Jenderal Pendidikan Islam merupakan pihak yang membuat aplikasi EMIS Tanggap Covid-19. Hal tersebut juga sesuai dengan paparan Oprator EMIS yang menyatakan:

"iya aplikasi EMIS Covid-19 ini dibuat oleh pusat dan ada surat edaran dan panduannya. untuk mengakses EMIS Tanggap Covid-19 dibutuhkan User Id dan password yang sama dengan EMIS madrasah."

Sebagai pihak pembuat EMIS Tanggap Covid-19 Direktorat Jenderal Pendidikan Islam menjadi pihak yang merencanakan aplikasi EMIS Tanggap Covid-19 mulai dari menentukan penguna EMIS Tanggap Covid-19, kebutuhan data yang mencakup kriteria kesiapan lembaga pendidikan islam di masa pandemi Covid-19.

- Perencanaan perangkat keras dan perangkat lunak

Perangkat keras yang digunakan untuk mengakses EMIS Tanggap Covid-19 adalah perangkat komputer dan jaringan internet. Sedangkan untuk perangkat lunak berupa data base dan situs web EMIS Tanggap Covid-19. Untuk mengakses EMIS Tanggap Covid-19 diperlukan user id dan possword yang disesuaikan dengan user id dan password yang dimiliki lembaga untuk mengakses EMIS.

Dari paparan diatas dapat disimpulkan Direktorat Jenderal Pendidikan Islam Kementerian Agama RI merupakan pihak yang merencanakan dan membuat aplikasi EMIS Tanggap Covid-19. Perencanaan aplikasi EMIS Tanggap Covid-19 meliputi pemetaan pihal penguna yang memerlukan data seputar kesiapan madrasah, memetakan macam-macam kebutuhan data, membuat instrumen 
pengumpulan data disertai pedoman pengisiannya, dan menyiapkan User id dan password untuk mengakses web EMIS Tanggap Covid-19.

Selanjutnya yaitu tahap pelaksanaan EMIS Tanggap Covid-19 yang dilakukan melalui serangkaian kegiatan, diantaranya:

- Sosialisasi Pengisian Daftar Kesiapan Madrasah

Sesuai surat edaran dari Direktorat Jenderal Pendidikan Islam Kementerian Agama RI, Oprator EMIS pada seksi Pendidikan Madrasah Kementerian Agama Kabupaten Mojokerto melakukan sosialisasi pengisian daftar kesiapan proses belajar mengajar satuan pendidikan di masa pandemi Covid-19. Sosialisasi dilakukan secara online melalui grup WA. Pada kegiatan sosialisasi Oprator EMIS memberitahukan kelengkapan yang perlu disiapkan oleh madrasah dan menunjukan panduan pengisian EMIS Tanggap Covid-19, hal ini seperti yang dipaparkan oleh Oprator EMIS:

“terkait EMIS Tanggap Covid-19 kita mensosialisasikan ke lembaga lewat WA, sosialisasi dilakukan untuk memberitahukan kelengkapan yang harus disiapkan lembaga dalam mengisi EMIS Tanggap Covid-19. Sebelum mensosialisaikan pada lembaga kita mendapatkan sosialisasi dari kanwil."

Pada saat sosialisasi Oprator EMIS juga memberitahukan bahwa batas waktu pengisian daftar kesiapan satuan pendidikan pada tanggal 26 Juni 2020. Proses sosialisasi berjalan dengan lancar karena pada panduan daftar kesiapan satuan pendidikan dijelaskan secara jelas dan detail cara-cara dan kelengkapan data yang dibutuhkan. Dan apabila pihak madrasah mengalami kesulitas akan di bantu oleh Oprator EMIS.

- Pengisian Daftar Kesiapan Madrasah

Setelah mendapatkan sosialisasi, madrasah bisa mengisi EMIS Tanggap Covid-19 dengan mengakses melalui laman web https://emisdep.kemenag.go.id. Sesuai yang tercantum pada panduan mengisi daftar pertanyaan yang terbagi menjadi 4 menu yaitu ketersediaan sanitasi, ketersediaan fasilitas kesehatan, pemetaan warga satuan pendidikan, dan kesepakatan. Oprator 
EMIS madrasah harus menjawab pertanyaan pada masing-masing menu dengan memilih jawaban tersedia atau tidak tersedia. Jika tersedia maka harus dilampirkan foto atau dokumen pendukung sesuai yang diminta setiap pertanyaan. Namun bila tidak tersedia isikan langkah tindak lanjut pada kolom tindak lanjut.

- Pengelolaan Data Kesiapan Madrasah

Setelah madrasah di mengisi daftar isian kesiapan satuan pendidikan data akan muncul pada EMIS Tanggap Covid-19 Kemeterian Agama Kabupaten/Kota. Dari hasil isian tersebut Oprator EMIS dapat melihat sejauh mana kesiapan madrasah memulai kembali memulai pembelajaran tatap muka dengan melihat kriteria yang sudah dipenuhi oleh madrasah. Jika madrasah telah memenuhi semua kriteria Oprator EMIS akan melakukan verifikasi dan validasi data. Dengan dilakukannya verifikasi dan validasi maka madrasah bisa mulai kembali pembelajaran tatap muka.

Pada EMIS Tanggap Covid-19 Kementerian Agama Kabupaten/Kota terdapat 4 menu yaitu: Siap verval, berisi data madrasah yang sudah mengisi daftar kesiapan satuan pendidikan dan siap untuk di verifikasi dan di validasi oleh oprator EMIS; verval (disetujui), berisi data madrasah yang sudah di verifikasi dan di validasi oleh oprator EMIS' verval (tidak disetujui), berisi data madrasah yang belum d verifikasi dan di validasi oleh oprator EMIS; Belum Lengkap, berisi data madrasah yang sudah mengisi daftar kesiapan satuan pendidikan namun belum melengkapi 4 kriteria.

Hal tersebut seperti yang dipaparkan oleh oprator EMIS yang menyebutkan bahwa

"Menunya adalah siap verval artinya siap disetujuai, verval disetujui artinya madrasah sudah melengkapi semua data dan sudah di verval, yang ketiga verval tidak setujui berarti kelengkapannya tidak lengkap, dan keempat belum lengkap yang artinya sama belum melengkapi kriteria."

Dari paparan mengenai pelaksanaan EMIS Tanggap Covid-19 dapat disimpulkan terdapat tiga tahap pelaksanaan EMIS Tanggap 
Covid-19 yaitu sosialisasi, pengisian daftar kesiapan satuan pendidikan yang dilakukan madrasah, dan pengelolaan data dengan melakukan verifikasi dan validasi pada madrasah yang telah memenuhikriteria kesiapan madrasah memulai kembaliproses pembelajaran tatap muka pada masa pandemi Covid-19.

Selanjutnya adalah evaluasi EMIS Tanggap Covid-19. Evaluasi merupakan hal utama yang dilakukan oleh manajemen untuk mengetahui permasalahan yang ada dalam EMIS Tanggap Covid19. Dari permasalahan yang ada akan ditentukan solusi untuk memperbaiki masalah tersebut. Menurut paparan Oprator EMIS menjabarkan:

“Untuk saat ini aplikasi EMIS Tanggap Covid-19 sudah cukup memadai untuk digunakan memantau kesiapan madrasah. kekurangannya terletak pada jaringan internet sehingga server akan sering eror."

Dalam impelmentasinya EMIS Tanggap Covid-19 dirasa cukup memadai untuk memantau kesiapan madrasah memulai pembelajaran tatap muka karena didalamnya memuat kriteria yang sesuai untuk menilai kesiapan madrasah dan mampu memberikan data yang valid mengenai kesiapan madrasah memulai pembelajaran tatap muka. Selain itu dengan menggunakan EMIS Tanggap Covid-19 pelaksanaan pemantauan kesiapan madrasah dapat dilakukan secara efektif dan efisien.

Dari paparan diatas dapat disimpulkan bahwa dengan menggunakan EMIS Tanggap Covid-19 dapat diperoleh data yang valid dan proses pemanatan kesiapan madrasah dapat dilakukan secara efektif dan efisien.

Manfaat adanya EMIS Tanggap Covid-19 dalam pemantauan kesiapan madrasah selama terjadinya pandemi Covid-19 yaitu Seksi Pendidikan Madrasah sebagai lembaga yang menaungi madrasah mengetahui sejauh mana kesiapan lembaga dalam memulai kembali pembelajaran tatap muka yang meliputi kesediaan sanitasi, fasilitas kesehatan, pemetaan warga sekolah, dan kesepakatan. Seperti yang dijelakan oleh Oprator EMIS yaitu: 
"kita mengetahui sejauh mana kesiapan lembaga terhadap sarana dan prasarana yang terkait protokol kesehatan, dengan EMIS ini kita tahu lembaga mana yang sudah siap dan belum siap, jadi kita bisa melihat sarana seperti apa, fasilitasnya seperti apa, kesepatakan dengan komite ada atau tidak".

Hasil pemantuan pada Aplikasi EMIS Tanggap Covid-19 menunjukan dari 520 madrasah di Kabupaten Mojokerto terdapat 378 madrasah yang sudah mengisi daftar kesiapan satuan pendidikan. 142 madrasah lainnya belum mengisi daftar kesiapan satuan pendidikan. Berikut ini rekap data jumlah madrasah yang telah mengisi/merespon atau belum mengisi/belum merespon daftar kesiapan satuan pendidikan yang diperoleh dari EMIS Tanggap Covid-19:

\begin{tabular}{|c|l|c|c|c|}
\hline No. & \multicolumn{1}{|c|}{ Jenjang } & Merespon & $\begin{array}{c}\text { Belum } \\
\text { Merespon }\end{array}$ & Total \\
\hline 1. & $\begin{array}{l}\text { Roudhatul Athfal } \\
(\text { RA) }\end{array}$ & 149 & 39 & 188 \\
\hline 2. & $\begin{array}{l}\text { Madrasah } \\
\text { Ibtidaiyah (MI) }\end{array}$ & 147 & 54 & 201 \\
\hline 3. & $\begin{array}{l}\text { Madrasah } \\
\text { Tsanawiyah (MTs) }\end{array}$ & 52 & 31 & 83 \\
\hline 4. & $\begin{array}{l}\text { Madrasah Aliyah } \\
\text { (MA) }\end{array}$ & 30 & 18 & 48 \\
\hline \multicolumn{2}{|l|}{ Total } & 378 & 142 & 520 \\
\hline
\end{tabular}

Dari tabel tersebut diketahui jenjang RA yang telah merespon sebanyak 149 madrasah, jenjang MI yang telah merespon sebanyak 147 madrasah, jenjang MTs yang telah merespon 52 madrasah, dan pada jenjang MA terdapat 38 madrasah yang telah merespon Daftar Kesiapan proses belajar mengajar satuan pendidikan pada masa pandemi Covid-19.

Dari 378 madrasah yang telah merespon belum mendapat verifikasi dan validasi dari Oprator EMIS pada seksi Pendidikan Madrasah Kementerian Agama Kabupaten Mojokerto karena dari 
378 belumada yang mendapat rekomendasi dari Satuan Gugus Tugas Covid-19 dikarenakan Kabupaten Mojokerto termasuk zona merah. Dari hasil pemantauan tersebut diketahui bahwa seluruh madrasah di Kabupaten Mojokerto belum diperbolehkan memulai pembelajaran tatap muka. Hal ini sesuai dengan paparan yang dikemukakan oleh Oprator EMIS:

"Dari semua madrasah yang mengisi ini belum ada satupun yang kami setujui terkait permohonan pada EMIS Covid-19 dengan pertimbangan belum mendapat rekomendasi dari satgas Covid-19 dan satgas Covid-19 belum merubah status kabupaten Mojokerto dari zona merah menjadi zona hijau, ketika satuan gugus tugas telah merekomendasikan mojokerto telah menjadi zona hijau maka madrasah yang sudah merespon EMIS Covid dan memenuhi 4 kriteria ini akan kami setujui semuannya untuk melakukan pembelajaran tatap muka."

Jadi diketahui syarat penting selain 4 kriteria yang harus dimiliki oleh madrasah untuk memulai kembali pembelajaran tatap muka adalah mendapat rekomendasi dari Satuan Gugus Tugas Covid-19 yang menyatakan Kabupaten Mojokerto termasuk zona hijau. Selain pemantauan melalui aplikasi EMIS Tanggap Covid-19 untuk mengecek kebenaran data di madrasah, Pengawas madrasah bertugas melakukan verifikasi lapangan pada tiap madrasah untuk memilai kesiapan madrasah dengan melihat 4 kriteria yang telah ditetapkan sebelumnya. Dokumen hasil verifikasi lapangan di berikan pada seksi Pendidikan Madrasah sebagai syarat verval di EMIS Tanggap Covid-19. Hal ini sesuai yang dijalaskan oleh Oprator EMIS:

"iya jadi lembaga yang telah mengisi EMIS Tanggap Covid19 akan ada verifikasi lapangan yang dilakukan oleh pengawas madrasah, pengawas madrasah memonitoring dan menilai secara langsung kelengkapan 4 kriteria yang ada sudah terpenuhi atau belum. Jika pada verifikasi lapangan tersebut madrasah sudah memenuhi semua kriteria akan mendapat surat keterangan verifikasi yang 
ditanda tangani oleh, dan dokumen hasil verifikasi lapangan akan dikirim ke kantor sabagai syarat persetujuan dilaksanakaannya pembelajaran tatap muka kemudian akan dilakukan verval melalui EMIS Tanggap Covid-19."

Dari hasil penelitian belum ada madrasah di Kabupaten Mojokerto yang mendapat izin untuk kembali melakukan pembelajaran tatap muka, namun pelaksanaan EMIS Tanggap Covid-19 dan pemantauan kesiapan madrasah tetap dilakukan seperti alur pelaksanaan EMIS Tanggap Covid-19 dan alur pemantauan kesiapan madrasah yang telah dijelaskan sebelumnya.

Terdapat beberapa faktor pendudukung implementasi aplikasi EMIS Tanggap Covid-19 dalam pemantauan kesiapan madrasah memulai kembali pembelajaran tatap muka, yaitu:

- Kompetensi Tenaga Administrator

Salah satu yang menjadi pendukung aplikasi EMIS Tanggap Covid-19. Tenaga administrator komputer yang handal dan profesional, karena semua proses kegiatan mulai dari penginputan data sampai pengelolaan informasi menggunakan sistem kompeter.

- Sarana dan prasarana

Faktor pendukung yang kedua adalah tersedianya sarana dan prasarana yang berimbas terhadap informasi yang diberikan kepada publik sangat ditunjang dengan adanya sarana dan prasarana. Prangkat lunak dalam pengelolaan informasi menggunakan website harus didukung perangkat keras yang baik misalnya VGA, memori, profesor, hardisk, dll.

- Komitmen madrasah

Faktor ketiga yaitu komitmen madrasah dalam mengisi daftar kesiapan proses belajar di satuan pendidikan. Madrasah di Kabupaten Mojokerto sebanyak 72\% telah merespon EMIS Tanggap Covid-19.

- Data yang valid

Kemudahan melakukan pemantauan kesiapan madrasah didukung dengan data yang valid karena dalam pengisian daftar kesiapan madrasah juga dilampirkan foto atau dokumen pendukung sebagai penunjang validnya data. Selain itu juga 
ditunjang dengan verifikasi lapangan sehingga bener-benar mendapatkan data yang valid sesuai di lapangan.

Adapun faktor penghambat implementasi aplikasi EMIS Tanggap Covid-19 dalam pemantauan kesiapan madrasah memulai kembali pembelajaran tatap muka, yaitu:

- Jaringan Internet

Ketika jaringan terganggu maka akan menghambat semua kegiatan khususnya ketika ingin mentransfer data dan informasi melalui internet. Sehingga mengakibatkan akses informasi dan komunikasi data lambat.

- Terdapat Madrasah yang Belum Merespon

Sebanyak 142 yang belum memberi respon pada EMIS Tanggap Covid-19 sehingga jika hal ini tidak segera ditindak lanjuti akan menghambat proses pemantauan yang dilakukan Kementerian Agama Kabupaten Mojokerto terhadap kesiapan madrasah pada masa pandemi Covid-19.

\section{Kesimpulan}

EMIS Tanggap Covid-19 (ETC-19) merupakan aplikasi berbasis web yang digunakan untuk mengakses daftar kesiapan proses belajar mengajar satuan pendidikan dimasa pandemi Covid-19. Pengelolaan EMIS terdiri dari tiga tahap yaitu perencanaan, pelaksanaan hingga evaluasi.

Perencanaan EMIS Tanggap Covid-19 dilakukan oleh Direktorat Jenderal Pendidikan Islam Kementerian Agama RI. Perencanaan aplikasi EMIS Tanggap Covid-19 meliputi pemetaan pihal penguna yang memerlukan data seputar kesiapan madrasah, memetakan macam-macam kebutuhan data, membuat instrumen pengumpulan data disertai pedoman pengisiannya, dan menyiapkan User id dan password untuk mengakses web EMIS Tanggap Covid-19.

Pelaksanaan EMIS Tanggap Covid-19 dapat disimpulkan terdapat tiga tahap pelaksanaan EMIS Tanggap Covid-19 yaitu sosialisasi, pengisian daftar kesiapan satuan pendidikan yang dilakukan madrasah, dan pengelolaan data dengan melakukan verifikasi dan validasi pada madrasah yang telah memenuhi kriteria 
kesiapan madrasah memulai kembaliproses pembelajaran tatap muka pada masa pandemi Covid-19.

Dari hasil evaluasi EMIS Tanggap Covid-19 menunjukan bahwa EMIS Tanggap Covid-19 memadai untuk pemantauan kesiapan madrasah. Dari EMIS Tanggap Covid-19 dapat diperoleh data yang valid dan proses pemanatan kesiapan madrasah dapat dilakukan secara efektif dan efisien.

Hasil pemantuan pada Aplikasi EMIS Tanggap Covid-19 menunjukan dari 520 madrasah di Kabupaten Mojokerto terdapat 378 madrasah yang sudah mengisi daftar kesiapan satuan pendidikan. 142 madrasah lainnya belum mengisi daftar kesiapan satuan pendidikan. Dari 378 madrasah yang telah merespon belum mendapat verifikasi dan validasi dari Oprator EMIS pada seksi Pendidikan Madrasah Kementerian Agama Kabupaten Mojokerto karena dari 378 belumada yang mendapat rekomendasi dari Satuan Gugus Tugas Covid-19 dikarenakan Kabupaten Mojokerto termasuk zona merah.

Faktor pendukung adanya aplikasi EMIS Tanggap Covid-19 dalam pemantauan kesiapan madrasah yaitu kompetensi Oprator EMIS, sarana dan prasarana, data yang valid, komitmen madrasah, sedangkan faktor penghambatnya yaitu sulitnya jangkauan jaringan untuk mengakses aplikasi Emis Tanggap Covid-19 di waktu-waktu tertentu dan terdapat 142 madrasah yang belum merespon.

\section{References}

Firdanti. Arinda. Implementasi Manajemen Berbasis Sekolah Dalam Meningkatkan Prestasi Belajar Siswa Yogyakarta: CV Gre Publishing. 2018.

Yuliana. "Corona Virus Diseases (Covid-19); Sebuah Tinjauan Literatur," Jurnal Wellness And Healthy Magazine 2, no. 1. (Februuary 2020): 187-182.

Mastura. Santaria. Rustan. “Dampak Pandemi Covid-19 Terhadap Proses Pengajaran Bagi Guru Dan Siswa.' Jurnal Studi Guru Dan Pembelajaran 3, no. 2 (Agustus 2020): 289-295. 
Bryan J.Kaleb, Lengkong, Victor P.K. "Penerapan Sistem Informasi Manajemen Dan Pengawasannya Di Kantor Pelayanan Pelayanan Pajak Pratama Manado" Jurnal Emba 7, no. 1 (Januari 2019) 781-790.

Surat Keputusan Bersama Menteri Pendidikan Dan Kebudayaan, Menteri Agama, Menteri Kesehatan, Dan Menteri Dalam Negeri Republik Indonesia Nomor 01/Kb/2020, Nomor 516 Tahun 2020, Nomor Hk.03.01/Menkes/363/2020, dan Nomor 440-882 Tahun 2020 Tentang Panduan Penyelenggaraan Pembelajaran Pada Tahun Ajaran 2020/2021 Dan Tahun Akademik 2020/2021 Di Masa Pandemi Corona Virus Disease 2019 (Covid-19). Tanggal 15 Juni 2020.

Surat Edaran dari Kemeterian Agama Republik Indonesia prihal Pengisian Daftar Periksa Kesiapan Satuan Pendidikan Di Bawah Naungan Ditjen Pendidikan Islam Memasuki Tahun Ajaran Baru Di Masa Pandemi Covid-19. Tanggal 26 Juni 2020.

Ruang Pendidikan. "Panduan Pengisian Emis Tanggap Covid (ETC)". Tanggal terbit 17 Juni 2020. diakses pada 01 Oktober 2020. di https://www.ruangpendidikan.site/2020/ 06/panduan-pengisian-layanan-emis-tanggap-covid-19.html.

EMIS Tanggap Covid-19. diakses pada 1 Oktober 2020 di http://emisdep.kemenag.go.id/e-tc19/

Internasional Kontan. "Ini 10 Negara dengan Kasus Covid Terbayak Di Muka Bumi”. tanggal terbit 7 Juli 2020. Di akses pada 7 Oktober 2020. https://www.google.com/amp/s/amp.kontan.co.id/news/selas a-7-juli-2020-ini-10-negara-dengan-kasus-covid-19-terbanyakdi-muka-bumi

Kompas. "Update Covid-19 dubia 5 Oktober: 35,38 Juta Orang Terinfeksi Virus Corona". tanggal terbit 5 Oktober 2020. $\begin{array}{lllll}\text { diakses } & \text { pada } & 7 & \text { Oktober } & 2020 \\ \text { di }\end{array}$ https://www.google.com/amp/s/amp.kompas.com/tren/read/2 
Fitria Hindahsari, Rizki Ayuningtyas, Wahyu Aji Lusdianto.

020/10/05/073710265/update-covid-19-dunia-5-oktober-3538juta-orang-terinfeksi-virus-corona.

Tribunnews. “Update Covid-19 Global 4 Okober 2020: Indonesia Urutan ke 3 Negara Di Asia Dengan Kematian Tertinggi". tanggal terbit 4 Oktober 2020. di akses pada 7 Oktober 2020. Di https://www.google.com/amp/s/m.tribunnews.com/amp /corona/2020/10/04/update-covid-19-global-4-okober-2020indonesia-urutan-ke-3-negara-di-asia-dengan-kematiantertinggi. 